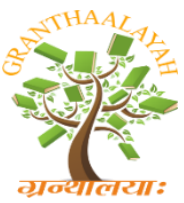

$$
\begin{aligned}
& \text { INTERNATIONAL JOURNAL OF RESEARCH - } \\
& \text { GRANTHAALAYAH } \\
& \text { A knowledge Repository }
\end{aligned}
$$

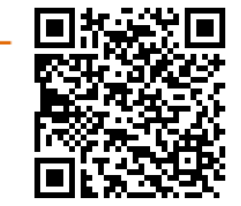

Social

\title{
INFECTIOUS DISEASES AND THE ENVIRONMENT: BASELINE INFORMATION FROM STAKEHOLDERS IN CROSS RIVER STATE, NIGERIA
}

\author{
Osuchukwu, N. C ${ }^{1}$, Agba, A. M. Ogaboh ${ }^{* 2}$, Emeh, J. U. ${ }^{3}$ \\ ${ }^{1}$ Lecturer, Department of Public Health, University of Calabar, Calabar, Nigeria \\ ${ }^{* 2}$ Lecturer, Department of Sociology, University of Calabar, Calabar, Nigeria \\ ${ }^{3}$ Lecturer, Department of Curriculum and Teaching, University of Calabar, Calabar, Nigeria
}

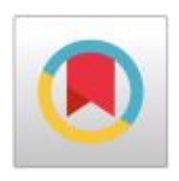

DOI: https://doi.org/10.29121/granthaalayah.v5.i1.2017.1889

\begin{abstract}
The prevalence of environment related infectious diseases in sub-Saharan Africa despite concerted efforts to prevent and reduce its spread is worrisome. African remains the continent that pays the greatest prince, bearing roughly two-third-of mortality burden from infectious diseases. The concern of this study therefore is to examine reactions from stakeholders in Cross River State, Nigeria on the state of the environment, education/curriculum and the spread of infectious diseases. Seventy (70) stakeholders were purposively selected for the study. Qualitative technique that is Focus Group Discussion (FGD) was used to generate data from selected participants. Five FGDs comprising of fourteen (14) persons each was used for the study. Group discussions were based on themes/questions that reflect on the environment, infectious diseases and the curriculum in primary and secondary schools. Baseline information from participants revealed that curriculum contents at primary and secondary education levels do not adequately address issues of infectious diseases and the environment. We recommended among others the infusion of vital aspects of infectious diseases (ID) and environmental education (EE) in the curriculum contents of primary and secondary schools in Nigeria.
\end{abstract}

Keywords: Infectious Diseases; Environment; Environmental Education; Mortality and Human Development.

Cite This Article: Osuchukwu, N. C, Agba, A. M. Ogaboh, and Emeh, J. U.. (2017). "INFECTIOUS DISEASES AND THE ENVIRONMENT: BASELINE INFORMATION FROM STAKEHOLDERS IN CROSS RIVER STATE, NIGERIA.” International Journal of Research - Granthaalayah, 5(1), 263-281. 10.29121/granthaalayah.v5.i1.2017.1889.

\section{Introduction}

Infectious diseases also known as contagious diseases (Chivian, 2001) are one the major cause of death in the world today, responsible for about seventeen (17) million deaths annually. This 
surpasses deaths from all wars of the twentieth century which is put at about 1.1 million yearly for both combats and civilians (Emeh, 2011). Sub-Saharan Africa so far is the most affected worldwide; nearly half death cases caused by infectious diseases worldwide occur in Africa (Asuquo, 2011). The continent pays the greatest price; it accounts for two-thirds of the global mortality burdens emanating from three major pandemic of HIV/AIDS, Malaria and Tuberculosis (Emeh, 2011).

Infectious diseases accounts for twenty nine (29) from the ninety six (96) primary causes of mortality (World Health Organization WHO, 2006; Eni, 2011). The emergence, re-emergence and spread of infectious diseases are linked to ecological degradation (Baker, 1989). Climate change accounts for the rising incidence of previously suppressed infectious diseases in the world; and this is through increasing the temperatures under which many diseases flourish (Akogbeto, 2000; Amerasinghe, 2003). According to Emeh (2011), six per cent (6\%) of malaria cases in Nigeria during the last 25 years resulted from climate change.

While the emergence and re-emergence of infectious diseases is attributed to climate change; there is plethora of scientific evidence that climate change is human-induced. And this change places future generation at greater risks of surviving and escaping the scourge of poverty and human misery (United Nations Development Programme, UNDP; 2008). Evidently, climate change are caused by man's activities such as industrialization, transportation, mining, deforestation, road building etc (Amerasinghe, 2003; Zimmerman, 2007). Concerted global efforts have been made to cortile human activities that promote climate change and escalate the spread of infectious diseases (Eriger \& Smith, 2004; Eni, 2005; Santra, 2006; United Nation, 2009; Dvorsky, 2010). These efforts yielded little or no fruits in fighting climate change and the spread of infectious diseases. Climate change continues to define and shape prospects of human development in all ramifications (Heart, 2007) and affected person (APs) are rising annually (UNDP, 2008). According to Dvorsky (2010), there is still much to be done to fight climate change and its negative consequences especially on human health. Agba, Ushie and Agba (2007) posit that man is the most important factor in infighting health, poverty and environmental issues. Man's education on the environment and infectious diseases is vital in this endeavour. The degree at which a country's schools offer an enabling environment for all will go a long way in determining whether its next generation educated youth are healthy in body, mind and spirit. Implementing an effective educational health scheme that includes an environment that is supportive of socio-physical and emotional well-being is a feasible way to address the goals of "Health for All" and "education for All".

The generation of baseline data from stakeholders in the education and health sectors and even the family on the present state of curriculum content, the environment and the spread of infectious diseases in Nigeria is a milestone in the endeavour; and this study is geared towards achieving that. The basic assumption is that, these crops of stakeholders had wealth of experiences and are conversant with aspects of Nigeria curriculums that deal with environmental education and infectious diseases and are judge capable of making significant contributions on how education could help fight the scourge of infectious diseases and prevent its re-emergence. 


\subsection{Background Description of the Study Area}

Participants for this study were purposefully selected from Southern Sensational District of Cross River State Nigeria. The senatorial district is situated in the extreme south of Cross River State (Nkongen, Agba, Okoro \& Ushie, 2009). It is bordered on the north by Yakurr Local Government Area, in the east by Republic of Cameron, in the south by the Atlantic Ocean, in the west and south west by Eboyi and Akwa Ibom States respectively.

The Southern Senatorial District comprises of seven (7) LGA and these are Bakassi, Calabar south and Municipality, Akamkpa, Odukpani Akpabuyo, and Biase Local government area (Agba, Nkpoyen \& Achime, 2010). Apart from the headquarters of these local government areas, other towns and villages are rural communities; and most of it population engaged in agriculture as a means of livelihood. Agro industrial are establishing in the district to utilize produce from farmers (Agba \& Ushie, 2003). The people of the senatorial district also engaged in trade, fishing and craft making, which is evident in their culture. The district is blessed with resources such as granite, ginelina, lime stone, rubber, gravel, forest, river sand and laterite.

Southern Senatorial district is the commercial nerves of Cross River State and a home of diverse institutions of learning, from where participants for this study were selected. Historically the people of Southern Senatorial District are of the Bantu stock migrants from central Africa and this could account for their agricultural activities. Poverty in the senatorial district is significantly high and is skyrocketing due to climate change and policies inconsistency of government; forty per cent of its population are illiterates and youth unemployment is on the increase (Agba, et al., 2009). Located in tropical rain forest belt, the area is endemic with onchocerciasis; and the prevalence level is put at 10.13 per cent (Charles, et al., 2007). Other environment related diseases in the area include water and air bone diseases. The selection of stakeholders from this region for study is therefore crucial and important.

\section{Literature Review}

\subsection{Infectious Diseases and the African Continent}

Infectious diseases caused 17 million deaths each year that is one-third of annual mortality for the entire planet. Sub Saharan Africa, although home to only ten per cent $(10 \%)$ of the world's population, accounts for about 4 million mortality from infectious diseases such as AIDS, Tuberculosis and malaria alone. Of the 38.6 million people living with HIV/AIDS virus in 2005, sub-Saharan Africa accounts 24.5 million, from the 4.1 million newly reported cases , about 2.3 million and 3.1 million were from the same region (African Union, 2006; Emeh, 2011).

The African continent accounts for about a quarter of tuberculosis related infections and death in 2004. According to WHO (2006), nine million people contacted the tuberculosis disease in 2004, over 2 million of them died from the disease. The increased cases of tuberculosis is closely related to the increasingly spread of the HIV virus. On malaria, it accounts for 90 per cent of the 350-600 million clinically reported cases yearly in sub-Saharan Africa (Emeh, 2011). African and Asia are the most affected continents in the world in terms of pulmonary diseases, diarrhoea disease and measles (WHO, 1999). Infants and growing children accounts for over 600,000 
deaths from pneumonia in Africa each year. Also diarrhoea accounts for over 400,000 deaths in the African continent (Emeh, 2011). Those infectious diseases that are waterborne, have a high rate of mortality in Africa (see Table. 1).

Table 1: Selected Waterborne Diseases in Africa

\begin{tabular}{|c|c|c|}
\hline Condition & $\begin{array}{l}\text { Cases in Africa (in } \\
\text { millions) }\end{array}$ & $\begin{array}{l}\text { Proportion of global burden in } \\
\text { Africa (in percentage ) }\end{array}$ \\
\hline Hookworm & 198 & 34 \\
\hline Ascariasis & 173 & 22 \\
\hline Schistosomiasis & 166 & 89 \\
\hline Trichuriasis & 162 & 26 \\
\hline Trachoma & 33 & 40 \\
\hline Lymphatic filariasis & 46 & 38 \\
\hline Onchocerciasis & 18 & 99 \\
\hline
\end{tabular}

Source: Imperial College, London (www.imperial .ac.uk/8089. 1tm).

Infectious disease is a serious problem for the African continent and a burden for the regional bodies and individual nation government and is threatening the social and economic fabrics of the continent. Being the main cause of death among growing children and youths, infectious diseases affects social class that are of great importance to the socioeconomic development of the continent. In particular, the HIV/AIDS epidemic is causing serious health issues on the teaching profession and other occupation. For example, it has been estimated that about 815 Zambian primary school teachers died from AIDS related illness in 2001, which is about 45 per cent of the country's teaching population. With this, the chances of reaching the goal of stopping the spread of the disease is very slim. How is it then possible to achieve one of the millennium goal of primary education for all under these condition? Global Fund (GF) international maintain that, to achieve the aim of stopping the spread of AIDS, tuberculosis and malaria, will cost in the region of 12 billion dollars in GDP every year for African nations alone. This would induce gap in economic growth of the continent (Emeh, 2011). This gap according to WHO can be as high as 1.3 per cent per year, in which over a 15 -year period is synonymous to a roughly 20 per cent cut in gross nation product (GNP).

According to Asuquo (2011), there are 347 generic infectious diseases in the world today, 239 of these are potentially endemic to Nigeria. He posit that 65 per cent of all the deaths in subSaharan Africa are caused by infectious diseases; 90 per cent global malaria is in Africa while 40 per cent of all childhood diarrhoea occurs in Africa and most of these deaths are caused by only six deadly infectious - HIV/AIDS, malaria, diarrhoea, measles, tuberculosis and pneumonia.

\subsection{Impact of the Environment on Infectious Diseases}

The problem of environmental degradation and the continuous rise of different infectious diseases is a multifaceted, sometimes subtle one that is causing social scientist, increasing sleepless nights. Obviously, there linkage between the two phenomenon because infectious diseases are caused by the continuous presence and growth in the environment biological pathogens (Chivian, 2001). These pathogens such as parasites, prions, viruses, fungi, bacteria, and protozoa. The above named pathogens are the causes of diseases epidemics, without them, 
no infections epidemic occurs (Hay, 2000). The rising incidence of suppressed infectious diseases globally is linked to the dramatic environmental changes now sweeping the earth (Akogbeto, 2000). Instruments of change occur in variation, including the altering of Habitats or sites where vectors breed or reservoirs, host transfers and changes in host population density and biodiversity change (Eni, 2011). The Natural system are likewise sources of pathogens and the destruction of an ecosystem has led to the disappearance of the foci of diseases. These can be attributed to economic development rather than from disease control; however, the changes in the environment has been going on for millennium and is key source of disease control (Baker, 1989; Eni, 2011).

Continuous urbanization and inadequate waste water management plan in underdeveloped nation and the growth of population are among the vital elements in the spread of infectious diseases (Bielders, et al., 2001). The chemical and anti-bodies found in animal waste are making bacteria that cause disease more resistant to drugs with implications for infections such as hepatitis and some diarrhea diseases. Pollutions from automobiles and production factories are linked with increased frequency of respiratory infections. According to UNEP (2004), the worldwide outbreak of cholera can be linked to the continuous Pollution of coastal waters from raw untreated sewage. This shows that proper care and control of the social and physical environment will help in reducing outbreak and spread of infectious disease worldwide.

Taylor, et al. (2001) argued that diseases spread as a result of the activities of human that alters the physical environment and spread pathogens into new ecological habitats. For instance, the main anthropogenic drivers that affect disease risk include the obliteration of wildlife and reforestation; dynamics in surface water availability and distribution, land use plan for agriculture, crops and livestock proliferation, and disposal of chemical pollutant, which include pesticides and fertilizers, unplanned urbanisation; migration etc. Borges, et al. (1999) posit that, these anthropogenic drivers lead to change in the ecosystems that might lead to the emergence of disease via instruments that are more of infectious diseases.

Disturbing the ecosystem can Disturbance of ecosystem can have biological impact that influences the spread and transmission of diseases (Daszak, et al., 2001; Eni 2011). The irrigation system used for cultivating rice in the tropics has been linked to "vector-borne diseases such as malaria and Japanese encephalitis" (Amerainghe, 2003). Some of the ecological impact of irrigation system used in the growing of rice includes an increase in the breeding surface of mosquito .In rural India "irrigation malaria" was linked to the endemic transmission in the 1990s in a nation as populated as India, this was traced to the lack of maintenance of irrigations systems that brought situations that are suitable for the breeding of major vector such as culicificies (Eni, 2011).

The distribution and transmission of hymphatic filariasis, dengue fever, coccidiodomy cosis and leishmiasis are closely related to social, economic and behavioural elements in a population that is endemic (Amerasinghe, 2003). In the South-east part of Asia, Wucheria Bancroft infection, filarial nematodes is linked to very poor sanitation in urban areas, and this leads to an increase in the breeding of mosquito vector. Dengue fever is a tropical disease, but its prevalence is cause by increased number of imported cases, resulting from increased air travel and the introduction of Aedes albopictus, an exotic vector adapted to a cold climate. Uncontrolled urbanization around 
areas that are close to large forestation been typically linked with the advent of oropouche fever and mayaro fever viruses (Eni, 2011).

\subsection{Education and Infectious Diseases}

Researches have shown that the promotion and establishment of behaviours that are healthy for youths are very effective and easy than trying to put a stop or change their unhealthy behaviour (Lohnmann \& Wooley, 1988). Educational establishments plays a very important role in establishing and promoting healthy behavioural pattern among children and the youths which they imbibe and carry into adulthood (American cancer society, 2007). Each day at school gives millions of learners the chance to imbibe the need for healthy lifestyles and the skills needed to engaging in healthy behaviours and avoided or prevents the spread of infectious diseases. Schools also provide outlets for children and adolescents to engage in health behaviours such as eating healthy and participating in physical activities (WHO, 2007). Educational attainment can be linked to health in three major ways: social and psychological factors, health knowledge and behaviours, and employment and income (See figure 1 for details).

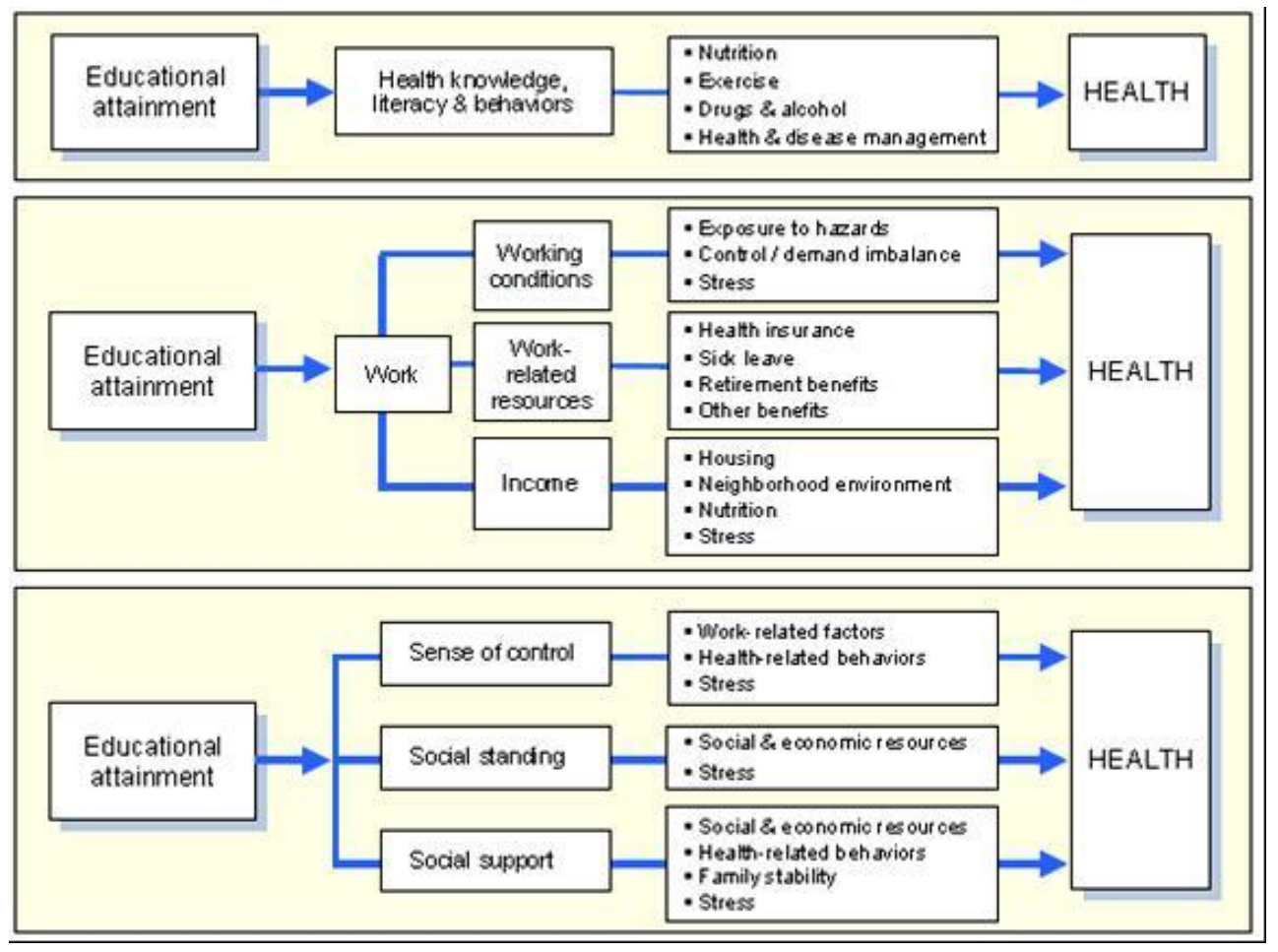

Figure 1: Interrelated pathway through which educational attainment affects health and the spread of infectious diseases

Source: Emeh, J. U. (2011: 15).

As depicted in figure 1, education increases people's knowledge and cognitive skills on diseases and this enables them to make and take good and informed choices on health related issues that are available to them and members of their family, including the ones relating to medical care (Williams, Baker \& Parker, 1998; Lee 1999; Cutler \& Lieras, 2006; Sanders, Federico \& Klass, 
2009). Good education can be associated with better promotion of healthy behaviour. This behaviours can include, an increase in the intake of vegetables and fruits and other aspects of healthy eating, engaging in physical exercise regularly and putting a restrain in the consumption of alcohol and cigarette smoking (Barbeau, Krieger \& Soobader, 2004; Kant, Graubard \& Kumanyika, 2007).

Educational attainment increases the degree at which people have the capacity to take in and understand basic information on health and those services that individuals need to make the right health decisions and also to obey complex diseases management protocols. Educational attainment also provides the knowhow and skills needed for gaining employment and this can shape health in many ways. Better education means better opportunity of getting employed and getting a job that offers healthy working condition, getting better employment benefits and better wages (Emeh, 2011). Education, by providing the basic skills and knowledge needed to compete in the labour market, is a key element in the promotion of social mobility and breaking the circle of intergenerational disadvantage and health related disparities (Rouse \& Barrow, 2006; Haveman \& Smeeding, 2006)

This suggests that, the healthy wellbeing of the Nigerian youth is not a matter of lack or the chance of some random event taking place, but something that must be planned. The need for a well-designed, resourced and sustainable health educational programme will help in reducing risky health behaviours such as the use of tobacco, poor nutritional practices, the use of alcohol as well as stress increasing behaviours and action and actions that increases the risk of injury and violence. health education that is taught by professionally trained health instructors provides the best means of promoting good and positive health behaviour among youths and children (Emeh, 2011).

Disappointing, the curriculum is Nigeria are inadequate to cater for the overall health education of youths; and where the curriculum content is adequate, the technique and methods of teaching is more theory-based than practical. According to Emeh, et al. (2010), curriculum contents in Nigeria gives little or no attention to the local environment or the needs of the people. They argue that that the unemployment situation and other social problems in Nigeria are not unconnected with the inadequacies in the countries curriculum contents and its implementation. Woolman (2001) posit that, the inability of Africa's curriculum to provide adequate manpower and equip in-coming generation on how to survive in their environment is worrisome. Emeh, et al. (2010) thus suggested that curriculum especially at primary and secondary levels should continuously be reviewed, developed, expanded and integrated to meet local and global needs.

\subsection{Efforts by Nigeria and other African Countries in Combating Infectious Diseases}

The high cost and implications of infectious diseases on the population especially in Africa, commands the commitments and efforts of governments across the continent. These efforts include:

Increased health budget to 15 per cent of public spending

As of today, only six nations have succeeded in reaching or have tried reaching the goal as declared by the Abuja Declaration of 2001 and reiterated by the African Union member state, 
health ministers (African Union, 2010) (AU) at the recently held Abuja Summit on HIV/AIDS, Tuberculosis and Malaria (ATM). A third of African Union governments have also allocated at least 10\% of their resources to the health sector (Special African Union, 2006).

\section{Make HIV/AIDS a Priority for National Development}

About Eighty per cent (8\%) of African Union nations have put in place agencies that are to coordinate the fight against the scourge of HIV/AIDS and also they have put in place strategic action plan.

\section{Introduce a strategic plan for Tuberculosis}

From the fifty three African nations evaluated, two-third have national co-coordinating agencies whose aims is to step up the fight against tuberculosis. Twenty of these nations are in the process of setting up locally based health delivery systems to fight tuberculosis (African Union, 2006).

Reducing the burden of Malaria by half by 2010

Every member nation of the African Union have entered into a partnership All AU countries have entered into "Roll Back Malaria (RBM)" partnerships. Regional Socioeconomic organizations have also added malaria programmers into their programmes and strategies (African Union, 2006).

Allocation of more Resources to meet the Abuja Declaration and Millennium Development Goals The African union member State health ministers at the Abuja summit agreed to commit more resources to the fight against infectious diseases and to manage these resources effectively so as to bring about health financing policies that will reduce healthrisk burdens for families, and to make sure that budgetary support mechanisms do not lessen the funding available for health (Resolution of the Ministers of Health Financing in Africa, Art. 9).

\section{Rolling back AIDS, Tuberculosis and Malaria:}

\section{Prevention and Control of HIV/AIDS}

On the issue of HIV/AIDS, some African nations have shown at an early stage that an efficient and effective prevention campaign can put a check on the spread of HIV/AIDS. Nations like Senegal, after the outbreak of the epidemic, without much delay put in motion actions introducing sex education into primary and secondary school curricula' they also put in place measures for the treatment of sexually transmitted infectious diseases and also encourage the use of condom among sexually active individuals. The effect was remarkable, as the prevalence rate has remained less than $2 \%$ all over the country (WHO, 1999).

With an intensive, wide ranging and target prevention programmes, a nation like Uganda cut the prevalence rate of HIV/AIDS to eight per cent (8\%) in 1999, and to $6.7 \%$ by 2005 , from about fourteen per cent at its peak period in the 1990s. Today, the declining rate of anti-retroviral drugs is giving grounds that there is hope for the treatment of the scourge HIV/AIDS. From the 4.6 million people living with the virus in Africa, $23 \%$ had undergone treatment with the antiretroviral drug by June 2006. Nations such as Rwanda, Namibia and Botswana, have achieved the $50 \%$ reduction in the spread and treatment of the disease (WHO, 1999). 


\section{Screening and Treatment of Tuberculosis}

On the issue of tuberculosis, the African continent was among the first to apply and make use of the Direct Observed Treatment Short course (DOTS method) where people suffering from the disease can be diagnosed and treated effectively and at a lower cost. Guinea, one of the African continent poorest nations, in the first four years of the programme doubled their screening rate and treated about 80 per cent of people suffering from the ailment. Also the detection of people suffering from tuberculosis rose by 23 per cent to about 50 per cent between 1995 and 2005 .

\section{Malaria Prevention and Treatment}

In fighting malaria, many African nations have achieve great results in the distribution of insecticide treated nets and the rate of coverage of children less than five years. At the end of 2005, more than 35 per cent of nations have adopted policies that include the using drugs that are effective against malaria. The "Roll Back Malaria" policies adopted by nations have helped given access to the use to artemisinin based drugs, which constitute a response to drug resistance.

\subsection{Major Obstacles Hampering the Fight against Infectious Diseases in Africa}

Even with the huge success achieved in the fight against infectious diseases in the world, Africa is still at a standstill and has achieved less in the fight against these diseases. First, the bulk of attention given to African countries in the treatment and prevention has been neither uniformed nor decisive. Even with the success made against HIV/AIDS, there is still the need to step up the pace of the treatment and prevention methods. Also, the success rate of the treatment of tuberculosis has been at a standstill since 1998b (Emeh, 2011).

Finally, not much progress has been achieved against those infectious diseases that have not attracted much attention. Diseases such as diarrhoea and pulmonary disease have combine to kill more African children than malaria. This can be attributed to lack of international attention and substantial funding at international level. Hardly has anything been done on the so called neglected tropical diseases, such as yellow fever, onchocercosis, trypanosomiasis, and schistosomiasis, even as these disease affects a large amount of people worldwide (WHO, 2005).These difficulties can be traced to some issues including insufficient co-ordination of: (i) resources; (ii) mechanisms to combat infectious diseases; and (iii) sectorial policies. They also arise from: (iv) excessive centralisation at the national level; and (v) underfunding.

\section{Insufficient Co-Ordination of the Means for Fighting Infectious Diseases}

First, the fact that there is a limited interaction between government and its agencies, the private sector and academic sector, when all combine their efforts together have the capability of fighting infectious disease means that resources allocated for fighting infectious disease are not been used optimally and effectively (Emeh, 2011) again, there is insufficient coordination among professionals working to reduce and stop the spread of infectious diseases that affects plant, animal and humans. Yet such diseases as AIDS, BSE/Creutzfeld-Jacob disease, SARS, avian flu, plague, etc. that have affected humans can be traced to animals. Furthermore, advancement in technological genomics and ICT has created opportunities that can be used in the diagnosis of and epidemiology of diseases (Emeh, 2011). A partnership between nations can help maximize the potentials of human resources, thanks to better sharing of data. 
Lack of co-ordination with other Sectors of Activity, such as Access to Water and Sanitation

The chief determinants of infectious disease are found other than in health, also in the field. Take Africa for example, the spread and emergence can be traced to population migration as a result of resettlement, conflict and unhealthy living conditions in shanties camps for refugees and makeshift houses (Garrett, 1996), changing climate conditions which leads to global warming and in extension the spread of certain vectors such as mosquitoes, and family dependence on certain energy sources that produces harmful smoke, and the lack of access to portable water and sanitation.

There is concern for vertical programmes, as enough attention have not been given to the physical environment that helps in the spread of infectious diseases. Particularly, eradication policies do not give sanitation and access to portable water the importance they deserve in fighting infectious diseases. Yet about 60 per cent of child mortality has been associated with infectious diseases, some of which are sanitation and water-related (WHO, 2005). Moreover, when compared to other continents of the world, Africa still has the lowest access to portable drinking water and sanitation (WHO, 2005).

\section{Theoretical Consideration}

In Africa, particularly in Nigeria, health seeking behaviour and the spread of infectious diseases is still being directed with multiple aetiologies. Studies have found socio-cultural and religious explanations for health seeking behaviours and the spread of infectious diseases. There is therefore no one theory that can explain explicitly the causes of diseases, its spread and possible treatment. Consequently, an eclectic approach consisting of biomedical and cultural theories was adopted in this study.

Biomedical explanation of diseases argues that exposure of one general virus, germs or bacteria are a necessary condition for the development, re-emergence and spread of infectious diseases. The theory looks at specific sources or causes of diseases which could be tackled in order to get the infected persons well again (Dubos, 1977).Although the theory seeks to advance specifics understanding of infectious disease, it has its limitations in the emergence of multiple aetiologies (Charles, et al., 2007). According to Wellin (1977), Ushie, Agba, and Ikoh (2010) people's beliefs and practices are influenced by their perception of the world. Charles et al (2007) posits that in a "worldview" controlled by magic, infectious diseases or ailment is perceived as function of "human or magical manipulations". Thus treatment can only be efficacious if a sorcerer or a pastor is consulted. This is opposed to scientific beliefs.

The theory of system and sub-system change established the relationship between medicine and the community. They theory drew heavily from the system theory; system and sub-system posit that the way of life and belief system in any society are not distinct, but part of the culture of the society (Lieban, 1977), culture in this regard is conceptualized as a system while the medical or institutions as sub-systems. Change in culture (system) affects the sub-system; similarly, change in the sub-system could also affects the entire system, (Wellin, 1977). Consequently, the health seeking behaviours of the people is influenced by the system or the subsystem; this in turn influenced the emergence, re-emergence and spread of infectious diseases. 


\section{Methodology}

Seventy (70) participants were purposefully sampled for the study. The study adopted the Qualitative technique (focus group discussions) in the process of gathering data from participants on the current state of curriculum contents on environment and infectious diseases. A breakdown of participants is shown below:

1) Primary school teachers

2) Secondary school teachers

3) Medical and paramedical personnel

$-7$

4) Lecturers from tertiary institutions

5) Principals

$-3$

6) Heads of primary school

$-3$

7) Parents

$-3$

Total

Other participants were special invited quests including: the University of Vice Chancellor; The Director of Academic Planning University of Calabar; Chief Medical Director University of Calabar Teaching Hospital and the Director of the Directorate of Research Centre, University of Calabar, Calabar. Participants were divided into 5 groups, comprising of 14 members each. The following curriculum themes (or questions) on the environment and infectious diseases were discussed:

Group 1: What is the current state of integrated curriculum contents for infectious diseases (ID) and environmental education (EE) at secondary and primary education levels in your school?

Group 2: What will be the objectives and justification of integrated curriculum contents of ID and EE at secondary and primary education levels in your school?

Group 3: What content areas currently exist now in ID and EE, and what areas would you suggest to be included in the existing subjects that can be taught to secondary and primary school students/pupils?

Group 4: What are the competencies (level of knowledge, beliefs, skills, attitudes and value orientations) of existing teachers in the area of ID and EE, and valid competencies required for them to teach infectious diseases and environmental education?

Group 5: What is the state of existing resources and infrastructure for effective teaching of these subjects, and what modern resources and infrastructure would now be needed for effective teaching in our respective schools?

\section{Findings from the FGDs}

Findings from focus group discussions are presented as follows:

Group 1: What is the current state of integrated curriculum contents for infectious diseases and environmental education at secondary and primary education levels in your school? 


\section{Reactions:}

1) The current curriculum on infectious diseases and environmental education at primary and secondary school levels is not comprehensive enough and should be separated from other major subjects like Biology, Physical Education, Social Studies, etc. and made compulsory.

2) During teachers' education, emphasis should be made on studies relating to ID and EE.

3) A little percentage of ID education is acquired courtesy of the HIV/AIDS awareness but almost no ideas on environmental education.

4) There is lack of well trained teachers, equipment and good laboratory for practical teaching.

5) Poor or inadequate education for the use of some modern facilities on health and the environment.

Group 2: What will be the objectives and justification of integrated curriculum content of ID and EE at secondary and primary education levels in our schools?

\section{Reactions:}

1) To inculcate in the learners the need for personal hygiene as a means of preventing infectious diseases (ID).

2) To create awareness on the learners on environmental education and environmental sanitation.

3) Imbibing the culture of positive values, beliefs and attitudinal changes for healthy living.

4) Arouse the learners' interest and curiosity in skills acquisition for self-reliance.

5) To educate the learner on the causes, effects and prevention of infectious diseases.

6) To encourage the learner to do regular exercises and be physically fit.

7) Assist the learners to adopt and practice behaviours that protect and promote health practices and reduce health risk.

8) Instil in the learner the need for the use of environment for sustainable development.

Group 3: What content areas currently exist now in ID and EE, and what areas would you suggest to be included in the existing subjects that can be taught to secondary and primary school students/pupils?

\section{Reactions:}

1) Infectious Diseases: HIV/AIDS, Malaria, Dengue Fever, Lymphatic diseases, Tuberculosis.

2) Environmental Education: Afforestation or bush burning, Urban air pollution, Indoor smoke, Road traffic injuries, Poor air quality, Climate change as a result of anthropogenic effect (bush burning, industrial activities, release of $\mathrm{CO}_{2}$, by human activities.

3) Subjects to be taught to schools: Afforestation, Environmental Sanitation, Proper waste disposal, Hand washing, Space for exercise and recreation. 
Group 4: What are the competencies (level of knowledge, beliefs, skills, attitudes and value orientations) of existing teachers in the area of ID and EE, and valid competencies required for them to teach infectious diseases and environmental education?

\section{Reactions:}

1) Level of knowledge: It is said knowledge is power. It is realized that not every teacher is vest with the subject-matter as teachings are in different area of specialization.

2) Retraining of Teachers: Teachers should be retrained in the areas of science like the Biology; because most students offer this subject in secondary schools and physical and health education in the primary schools.

3) Beliefs: Teachers should discard their traditional and religious beliefs and teach what is contained in the curriculum that is designed by the government.

4) Attitudes: Whether positive or negative, teachers should inculcate positive attitude in teaching.

5) Skills: Most teachers passed through poor background in either university or college of education; and because of lack of skills in imparting knowledge hence the need for training and retraining on this subject matter.

6) Values: A teacher who has a value for environmental education will do it better because some people do have something but they do not value it.

Group 5: What is the state of existing resources and infrastructure for effective teaching of these subjects, and what modern resources and infrastructure would now be needed for effective teaching in our respective schools?

\section{Reactions:}

With particular reference to Cross River State, the state of existing resources and infrastructure for effective teachings are:

1) Inadequate man-power: students/teacher ratio should be adequate.

2) Funding: provision of models, computers, internet systems, prints and non-prints, scientific equipment's, children friendly games, drama, songs, adverts, art works, outdoor activities, excursions, practical, projects and experiments.

3) Welfare: attractive pay package, uniformity of remuneration between public and private schools.

4) Training: regular training/retraining for teachers, workshops and seminars organized for the teachers.

Infrastructure:

1) Location of school in an environmental friendly location

2) Provision of adequate number of classrooms, departments

3) Provision of well-equipped laboratories

4) Provision of well-equipped ICT centre for research

5) Provision of adequate security measures to be put in place to cater or the safety of the equipment, staff and learners. 


\section{Discussion}

The study revealed that the current state of integrated curriculum contents for infectious disease (ID) and environmental education (EE) at primary and secondary educations levels is not comprehensive enough and should be separated from major subjects like biology, social studies, health education etc. The study also reveals that, teachers education on infectious diseases and the environment is not adequate. The study shows that negligible percentage of infectious diseases education is acquired courtesy of the HIV/AIDS awareness campaign and little is said about environmental education. This suggests that education at its present state in Nigeria cannot serve as instrument par excellence for the reduction of infectious diseases. According to Emeh (2011), education is crucial in the fight against the emergence, re-emergence and spread of infectious diseases in Africa, and should be encouraged by stakeholders.

Woolman (2001) argue that contents curriculums in Africa are inadequate to cater for the overall health education and social needs of the people. Emeh, et al. (2011) posit that since the curriculum content in Nigeria do not adequately address the problem of unemployment, and other social problem, fighting the spread of infectious diseases in the country will remain an uphill task. This suggest that, curriculum at primary and secondary school levels should continuously be reviewed, and expanded to meet the health and environmental needs of the present and future generation.

Ross and Mirowsky (1999), Cutler and Lleras (2006) maintained that there is a consistent evidence and argument, except with very rare exceptions that strongly links education to health, even with factors such as income taken into consideration. Braveman and Egerter (2008) are of the opinion that individuals with more education on infectious diseases and their environment are likely to live longer, experience better healthy living, with good health promoting behaviour such as regular exercise and with regular health check-up and screening.

We argue here that, the occurrence, outbreak and the spread of infectious diseases is greatly influenced by the environment. The environment here includes physical and social environment. It would be out of place to emphasize on one component of the environment at the expense of the other since both significantly affects infectious diseases the world over. While other scholars looks at the physical environment and infectious diseases, we posit that man's social environment especially his culture significantly affects his health seeking behaviour and the spread of infectious diseases. Culture here entails all human activities on the planet earth. It includes material (visible) and (invisible) activities of man. Culture in this regards can be divided into two components, viz: material and non-material culture. The production and distribution of artefacts could constitute a high profile challenge in the fight against climate change. As noted earlier, climate change is responsible for the rise and recurrence of infectious diseases especially in Africa and Asia. Gas emissions during manufacturing and distribution of artefacts (material culture) accelerate ecological problems globally. The use of these artefacts constitute yet another significant effect to global climate change; for instance, gas emissions especially $\mathrm{CO}_{2}$ from cars/automobiles, generators etc. accounts remarkably to global air pollution. Belief system, customs, norms and values could affect the environment, and the spread of infectious diseases. It could also affect the type of treatment or the health seeking behaviour of a given society. For 
instance, in some societies certain illnesses are seen as a curse from the gods, as such, treatment or cure can only be through consulting the oracle, priest or the native doctor.

Although other factors such as socio-economic activities of man and cultural variables could affect the environment and the spread of infectious diseases, we also opined that proper education could help reduce man-induced environmental change and it negative consequences on human health. Education could also shape the health seeking behaviour of our youths and the future generation; and could infuse heath elements in societal culture that promote proper health practices and behavioural change.

The study further reveals that integrated curriculum content of infectious diseases and environmental education at secondary and primary education levels would inculcate in the learner the need for personal hygiene as means of preventing the spread of infectious diseases. It would imbibe in the learner the culture of positive values, beliefs and attitude for healthy living. Integrated curriculum content of infectious diseases and environmental education would educate the learner on the causes, effects and prevention of infectious diseases. This implies that education could change the "world view" of the learner and this would promote good health seeking behaviour. According to Wellin (1972), Ushie, Agba and Ikoh (2010), people's beliefs and their health seeking behaviour are influenced by their perception of the world (or worldview). Charles, et al. (2007) argues that if the "worldview" of a people is dominated by spirituality or magic, sorcerers and pastors are sought for treatment of infectious diseases. This suggests that education on ID and the environment could propel cultural and attitudinal change among people on the best way of fighting infectious diseases in Nigeria.

Participants also suggested that subjects such as infectious diseases and environmental education should be infused in the existing curriculum in secondary and primary schools. The curriculum content on infectious diseases should include HIV/AIDS. malaria, dengue fever, lymphatic diseases and tuberculosis. While that of environmental education should include afforestation, urban pollution, indoor smoking, gas emission, and climate change. The exclusion of these variables in our present curriculum content is not unconnected with the high mortality rates in Nigeria. Emeh (2011), Asuquo (2011) and Eni (2011) all maintain that infectious diseases can be attributed to 29 of 96 main causes of mobility and mortality in the world; and the most affected is sub-Saharan Africa. World efforts to address this situation without pragmatic education is proving increases ineffective; suggesting that the infusion of the causes and preventions of infectious diseases in school curriculum especially at primary and secondary school levels is imperative and urgent.

The study further revealed that, teachers' level of knowledge, beliefs, skills, attitude and value in the areas of infectious diseases and environmental education is low because of their educational background. The study also revealed that existing resources in terms of infrastructure further affects teaching and learning. Participant posits that, school physical infrastructure such as models, computers, internet, printers, scientific equipment, outdoor sport facilities among others should be provided in primary and secondary schools to aid teaching of infectious diseases in Nigeria. Marinho (2009) argue that no curriculum would achieve its objectives in the absence of adequate human and material resources. This suggests that, education cannot serve as vital tool 
for fighting infectious diseases and controlling the environment in Nigeria until adequate resources are provided for this endeavour.

\section{Summary and Conclusion}

This study presents the African perspective of infectious diseases in terms of types, spread, and policy responses to this most pressing problem facing not only Africa but the world as a whole. We show the extent of the tragedy that has befallen our continent in the midst of fighting these diseases. The study also showed that the quality of the environment is significantly related to the distribution and intensity of these diseases. We highlighted the fact that man and his behaviour is a critical factor in the fight against infectious diseases and environmental disorganization. But since man is moulded by the school, education seems to infuse in him greater healthy attitudes, and behaviours, not only in his daily living, but in his relationship with fellow men and the environment. Therefore, systematic and health education offered to children from primary and secondary levels of education will help to increase awareness of the role of infectious diseases and their relationship to degraded environment. This will generate desirable attitudes, values, and commitments to healthy living that will be carried to adulthood. In conclusion therefore, educators and teachers are not medical doctors. They do not treat diseases, or carryout engineering activities for physical modification of the environment. Their professional training requires them to carry out relevant educational activities that will provide the following desirable outputs in all learners:

1) Acquisition of relevant concepts of ID and EE to be communicated, honestly and at a level understandable by the student/pupil in our schools.

2) Communication of positive values supportive of healthy living and environmental friendly behaviours, and which will increase the wellbeing of human populations.

3) Productions of desirable skills that will help our students/pupils live a socially healthy life in a healthy environment, resulting in increased quality of life for people nationally and globally.

4) Development of attitudes and beliefs supportive of health living, on the basis of awareness of casual factors that increase ID and environmental degradation, and thereby minimizing these problems

Education assumes that if children at primary and secondary schools levels can, in fact, be modified within the above framework, a cumulative effective will be produced that will help to minimize the problems of ID and EE, hence contribute to the achievement of MDGS. In this model, children who are aware can correct even their parents, modify their culture and promote good health seeking behaviour in their communities.

\section{Acknowledgements}

This research was sponsored by the Federal Republic of Nigeria assisted by World Bank. We also acknowledge the contributions of Late Professor John Emeh and other World Bank STEP-B University of Calabar team members who made this study possible. 


\section{References}

[1] African Union (May 2006), Special Summit on HIV/AIDS, Tuberculosis and Malaria, Concept Paper 180406 on HIV/AIDS, Tuberculosis and Malaria, Abuja,. http://www.abujaauatmsummit2006net/auatmsummitmain/summitdocs/Concept\%20paper\%2018 0406.pdf.

[2] Agba, A. M. \& Ushie, M. A. (2005). Improving the Niger Delta socio-economic status through active involvement of multinational corporations. Nigeria Journal of Social and Development Issues, 5(I), 63-74.

[3] Agba, A. M. O. Ushie, M. A. \& Agba, M. A. (2007). Effective adult education: A panacea towards poverty reduction in Nigeria. Giant of Academic, x(viii), 60-65.

[4] Agba, A. M. O., Nkpoyen, F. \& Achime, M. (2010). Women self-help imitative: A paradigmatic Shift in rural development. International Journal of Development and Management Review, 6(I), 50-61.

[5] Agba, A. M. O., Ushie, E. M. Ushie, M. A. Bassey A. O. \& Agba, M. S. (2009). Human development trend in Nigeria: The need for concrete implementation of the Seven Point Agenda. Nigerian Journal of Social and Development Issues, 6 (i), 15-28.

[6] Akogbeto, M. (2000). Lagoonal and coastal malaria at Contonou: Entomological Findings. Sante, 10(4), 267-275.

[7] Amerasinghe, F. P. (2003). Immigration and mosquito-borne disease. Journal of Parasitology, 89, 514-522.

[8] American Cancer Society (2007). Joint Committee on National Health Standards: National Health Education Standards. USA: American Career Society.

[9] Asuquo, A. E. (2011). Infectious diseases in developing countries: An overview. A paper presented on the $14^{\text {th }}$ of May, 2011 at stakeholders meeting organized by Centre of Excellence, World Bank Project 4, in University of Calabar, Calabar, Nigeria.

[10] Baker, R. (1989). Unpublished Report to OCP, Entomological Sierra Leone, April- August 1988.

[11] Barbeau, E., Krieger, N. \& Soobader, M. J. (2004). Working class matters: Socio-economic disadvantage, race/ethnicity, gender and smoking in National Health Insurance Scheme (2000). An J. Public Health, 94(2), 269-278.

[12] Bielders, C. L., Alvey, S. \& Crongn, N. (2001). Wind erosion: The perspective of grass-roots communities in the Sahel. Land Degradation and Development, 12, 57-70.

[13] Borges, E. C., Pires, H. H., Barbosa, SE., Nunes, C.M., Pereira, M. H., Romanha, A. J. \& Diotaiuti (1999). Genetic variability in Brazilian Triatomines and the risk of domiciliation. Members do Institute Osualdo Cruz, 94 (I), 371-373.

[14] Braveman, P. \& Egerter, S. (2008) Overcoming obstacles to health: Report from the Robert Wood Johnson Foundation to the commission to build a healthier America. Washington, DC: Robert Wood Johnson Foundation Commission to Build a Healthier America.

[15] Charles, J. O. et al (2007). Biomedical paradigm and cultural perception of on Chocerciasis in rural communities of Cross River State, Nigeria. African Journal of Public Health, 1(1), 57-70.

[16] Chivian, E. (2001). Species loss and ecosystem disruption: The implication from human health. Canadian Medical Association Journal, 164(1), 66-69.

[17] Cutler, D. \& Lleras, M. A. (2006). Education and health: Evaluating theories and evidence. Bethesda, M. D: National Bureau of Economic Research 200.

[18] Daszak, P. A., Cunningham, A. \& Hyatt, A. D. (2001). Anthropogenic environmental changes and the emergence of infectious diseases in wildlife. Ada Tropical, 78(2), 103-116.

[19] Dubos, R. (1977). Determinants of health and disease. In D. Landy (ed), Culture, disease and health: Studies in Medical Anthropology (31-41). New York: Macmillan Publishers.

[20] Dvorsky, G. (2010). Five reasons the Copenhagen Climate Conference failed. Online available at: http://ieet.org/index.php/IEET/more/dvorsky 20100110. Retrieved 31/5/10. 
[21] Emeh, J. U. (2011). Education versus infectious diseases (ID) and the environment. A paper presented on the $14^{\text {th }}$ of May, 2011 at stakeholders meeting organized by Centre of Excellence, World Bank Project 4, in University of Calabar, Calabar, Nigeria.

[22] Emeh, J. U., Abang, J. I. Asuquo, P., Kalu, I. \& Agba, A. M. O. (2011). Curriculum review: Reactions from education stakeholders in South-South States of Nigeria. Global Journal of Human Social Science, Vol. XI, Issue II, Version I, pp. 33-42.

[23] Eni, D. D. (2005). Philosophy and methodology of environmental science. Calabar: Ultimate Index Book Publishers.

[24] Eni, D. I. (2011). Environment and spread of infectious diseases in Nigeria. A paper presented on the $14^{\text {th }}$ of May, 2011 at stakeholders meeting organized by Centre of Excellence, World Bank Project 4, in University of Calabar, Nigeria.

[25] Eriger, E. D. \& Smith, B. F. (2004). Environmental science: A study of interrelationships New York: McGraw Hill Companies Incorporation.

[26] Garrett, L. (1996). The return of infectious diseases. Foreign Affairs, January/February 1996.

[27] Hart, J. (2008). Global warming. Online available at: Microsoft Encarta 2007; 1993-2006. Msenexml://content/761-567022? Masteruind; 1-9 Retrieved 30 /6/08.

[28] Haveman, R. \& Smeeding, T. (2006). The role of higher education in social mobility. Future Child, 16(2), 125-50.

[29] Hay, S. I. (2000). An overview of remote sensing and geodesy for epidemiology and public health Application. Advances in Parasitology, 47, 1-35.

[30] Wambete, M. (2006).Capacity Building: Hiv Positive teachers in Kenya. AIDS 2006, August 13$18^{\text {th }}$ 2006. Online available at: http://www.aids2006.org/.

[31] National technical working Group (2009). Report on the Vision 2020. National technical working group on Water and Sanitation. Online at http://www.infoforhealth.org/pr/m14/m14chap5.shtml\#top.

[32] http://www.uneca.org/ADF2000/Abuja\%20Declaration.htm\#top.

[33] Kant, A. K., Graudbard, B. I. \& Kumanyika, S. K. (2007). Trends in black-white differentials in dietary intakes of U.S. adults 1971-2002. Amj Prev Med, 32(4), 264-272.

[34] Lee, P. P. (1999). Why literacy matters: Links between reading ability and health. Arch Ophthalmol, 117(I), 100-103.

[35] Lieban, R. W. (1977). The field of medical anthropology. In D. Landy (ed), Cultural, disease and health: Studies in medical anthropology (pp. 13-31).

[36] Lohnmann, D. K. \& Wooley, S. F. (1998). Health is academic: A guide to coordinated school health programmes. New York: Teachers College Press.

[37] Marinho, S. (2009). An analysis of curriculum development and content delivery in Nigeria. Online available at: Http://quanesis.Com/Nigcurriculum.Pddf. Retried 2/1/11.

[38] Nkpoyen, F., Agba, A. M. O., Okoro, J. \& Ushie, E. M. (2009). External agents role in participatory rural community development in Cross River State, Nigeria. Leajon, I(I), 1-9.

[39] Resolution of the Ministers of Health Financing in Africa, Art. 9.

[40] Ross, E. E. \& Mirowsky, J. (1999). Refining the association between education and health: The effects of quality, credential and selectivity. Demography, 36(4), 445-460.

[41] Rouse, C. E. \& Barrow, L. (2006). U.S. elementary and secondary schools: Equalizing opportunity or replicating the status quo? Future Child, 16 (2), 99-123.

[42] Sanders, I. M. Federico, S. \& Klass, P. (2009). Literacy and child health: A systematic review. Arch Pediater Adolese Med, 163(2), 131-140.

[43] Santra, S. C. et al (2006). Environmental science. Kolkata: New Central Book Agency.

[44] United Nations (2009). United Nations Framework Convention on Climate change (UNFCCC). Online available at: blitems/4082.php. Retrieved 11/7/09.

[45] United Nations Human Development Programmes UNDP, (2008). UNDP Human Development Report2007/2008. New York: Mixed sources. 
[46] Ushie, E. M., Agba, A. M. O. \& Ikoh, M. U. (2010). Unpublished proposal for the integration of Community Directed Treatment with Ivermetin (CDTI) into Primary health Care (PHC) in Northern Senatorial District of Cross River State, Nigeria. Submitted to Coordinator, National Onchocerciasis Control programme, Federal Ministry of health, Abuja, Nigeria.

[47] Wellin, E. (1977). Theoretical - orientation in Medical Anthropology, Continuity and Change over the Past half Century. In D. Landy (ed.), Cultural, Diseases and Health: Studies in Medical Anthropology (31-41), New York: Macmillan Publishers.

[48] Williams M. V., Baker D. W. \& Parker, R. M. (1998).Relationship of Functional Health Literacy to Patients knowledge of their Chronic Diseases. A study of patients with Hypertension and Diabetes. Arch Intern Med, 158(2), 166-72.

[49] Woolman, D. C. (2001). Educational reconstruction and post-colonial curriculum development: A comparative study of four Africa countries. Internal Education Journal, 2(5), 27-46.

[50] World Health Organization (2007). Information series on school health: Skills for health. Online available at: http://www.who.mt/schoolyouthhealth/medialen/sch skillshealth03.pdf. Retrieved June 3, 2007.

[51] World Health Organization, WHO (2006) Global tuberculosis control report. Online available at: http://www.who.int/tb/publications/global_report/2006/pdf/full_report_correctedversion.pdf.

[52] World Health Organization, WHO, (1999). Report on Infectious Diseases, Removing Obstacles to Healthy Development, Geneva,. Online available at: http://www.who.int/infectious-diseasereport/index-rpt99.html.

[53] World Health Organization, WHO, (2005) Addressing the changing health challenges of the developing world, Geneva. Online available at: http://whqlibdoc.who.int/publications/2005/9241562986_part4.pdf.

[54] Zimmerman, M. (2007). Environment. Available at: Microsoft Encarta, 1993-2006. Msenexm//content/761566249? Jump; Retrieved 30/6/2008.

*Corresponding author.

E-mail address: ogabohagbagroup@yahoo.com 